\title{
Retraction of: Bone Mesenchymal Stem Cell-Conditioned Medium Regulates the Differentiation of Neural Stem Cells Via Notch Pathway Activation, by Li H-M, Tong Y, Xia X, Huang J, Song P-W, Zhang R-J, Shen C-L. Cell Reprogram. [Epub ahead of print; Dec 27, 2018] DOI: $10.1089 /$ cell.2018.0042
}

$\mathbf{T}$

He ONLINE-AHEAD-OF PRINT E-PUB VERSION of the article entitled, Bone Mesenchymal Stem Cell-Conditioned Medium Regulates the Differentiation of Neural Stem Cells Via Notch Pathway Activation, by Li H-M, Tong Y, Xia X, Huang J, Song P-W, Zhang R-J, Shen C-L, utilizing the DOI number 10.1089/cell.2018.0042 is being officially retracted from Cellular Reprogramming.

The original version of the paper was submitted to the journal for peer review on July 29, 2018, with the revised version after peer review submitted on October 21, 2018. The paper was accepted for publication on November 20, 2018 and was subsequently published online ahead of print on December 27, 2018. After the e-publication of the article, the editor received an email from the corresponding author on January 14, 2019 requesting "to withdraw the above-mentioned manuscript for further consideration, due to a technical reason (we have done a further experiment and found this article need add more results)."

Though it is unclear why the authors were not able to determine these faults with the paper within the six months the manuscript was in review, revision, and production, the editorial leadership of the Journal has determined that the paper requires a full retraction from the literature as Cellular Reprogramming is committed to upholding the strictest standards and best practices of scientific publishing. 